\title{
An improved methodology for synthesis of new Ugi adducts and its application in combinatorial synthesis
}

\author{
Sukhbir Kaur, ${ }^{\mathrm{b}}$ Vasundhara Singh, ${ }^{\text {a* }}$ Gulshan Kumar, ${ }^{\mathrm{a}}$ and Jasvinder Singh ${ }^{\mathrm{b}}$ \\ ${ }^{a}$ Department of Applied Sciences, PEC University of Technology, Chandigarh 160012,India \\ ${ }^{b}$ Department of Chemistry and Centre of Advanced Studies in Chemistry, Panjab University,
} Chandigarh 160014, India

Email:vasun7@yahoo.co.in

\begin{abstract}
New $\alpha$-acyl amino amides 1-7 have been prepared via Ugi four component condensation reaction in room temperature ionic liquid (bmim) $\mathrm{BF}_{4}$ in high yields and purity with good recyclability of the ionic liquid used. Various imidazole based ionic liquids were tried for this reaction and reaction conditions optimized for each of them. Several new Ugi adducts have been synthesized using the developed methodology on various substrates with easy recovery of the desired product and ionic liquid. The methodology was further extended to the synthesis of a small library of supported Ugi adducts in (bmim) $\mathrm{BF}_{4}$.
\end{abstract}

Key words: Ionic liquids, Ugi reaction, $\alpha$-acyl amino amides, combinatorial synthesis, recycling

\section{Introduction}

An ideal synthesis should lead to a desirable product in as few steps as possible, in good overall yields and through environmentally compatible reagents or solvents. ${ }^{1}$ Synthesis of the desired molecule can be achieved in a multi step fashion or it can be done in a one pot reaction of three or more starting materials well known as the multicomponent reactions (MCR's). The Ugi four component reaction $(\mathrm{Ugi}-4 \mathrm{CR})^{2}$ is an example of Domino reaction which has been widely employed to construct complex molecular structures with four points of diversity. A Ugi 4CR converts an aldehyde, an amine, a carboxylic acid and an isonitrile into $\beta$-lactam antibodies and related compounds, ${ }^{3,4}$ heterocycles with variable structures such as benzodiazepines, ${ }^{5}$ morpholines, ${ }^{6}$ tetrazoles, ${ }^{7}$ diketopiperazines ${ }^{8}$ and $\alpha$-aminobutyrolactones, ${ }^{9}$ in a single stage reaction with good yield.

The reaction is atom economical since only one molecule of water is lost and is hence, ecologically benign providing linear peptide like adducts, which are important skeletal structures for the synthesis of a number of medicinal and biologically important compounds such as 
antimalarial aminoquinoline analogous, ${ }^{10}$ cysteine protease inhibitors, ${ }^{11} \mathrm{D}$-phenylalanine derived factor $\mathrm{Xa}$ inhibitors ${ }^{12}$ and also for the preparation of enzyme electrodes.

The classical Ugi reaction is carried out in solvents such as methanol and dichloromethane under stirring at room temperature. ${ }^{13,14}$ Alternate solvents used in isocyanide based multicomponent reaction are water ${ }^{15}$ and trifluoroethanol. The use of volatile organic solvents is a subject of concern as they are harmful for the environment and are industrially unsuitable. To circumvent the problem of safe disposal of these solvents, development of newer methodologies and solvents such as the use of water, $\mathrm{scCO}_{2}$ and ionic liquids is a growing area in green synthesis. Ionic liquids are a class of solvents with fascinating properties such as tunable polarity, negligible vapour pressure and recyclability. ${ }^{16}$ A large number of reactions have been carried out in ionic liquids successfully ${ }^{17}$ resulting in enhanced reaction rates, improved yields and higher selectivity are remarkable features observed in ionic liquids in several cases as compared to conventional methods.

Soluble ionic liquids have recently been used as supports for catalyst/reagent immobilization and synthesis in homogeneous solution phase. ${ }^{18}$ The solubility properties of these ionic liquid supports can be tuned by varying the cations and anions to make them phase separate from less polar organic solvents and aqueous media. The ionic liquid supported species can therefore be purified from the reaction mixture by simple washings. Similarly, substrate solubility can also be tuned. ${ }^{19}$ This strategy makes it possible to use these low molecular weight ionic liquids as soluble supports for organic synthesis.

\section{Results and Discussion}

The imidazolium based ionic liquids are emerging as novel reaction media ${ }^{20}$ and with our interest in RTILs as catalysts ${ }^{21}$ and solvent, we have explored the use of ionic liquids as environment friendly solvent system for the synthesis of $\alpha$-acyl amino amides through Ugi four component reaction (Ugi 4CR) (Scheme 1). As a large number of ionic liquids with different physical and solubility properties are available, the choice of an appropriate ionic liquid is critical. By varying the anionic part of the ionic liquid we can modify the solubility, viscosity and melting point of the ionic liquid. Hence to carry out the reaction, the RTILs chosen were butyl-3-methylimidazolium hexafluorophosphate (bmim) $\mathrm{PF}_{6}$, butyl-3-methyl-imidazolium tetrafluoroborate (bmim) $\mathrm{BF}_{4}$ and butyl-3-methyl-imidazolium bromide (bmim)Br.

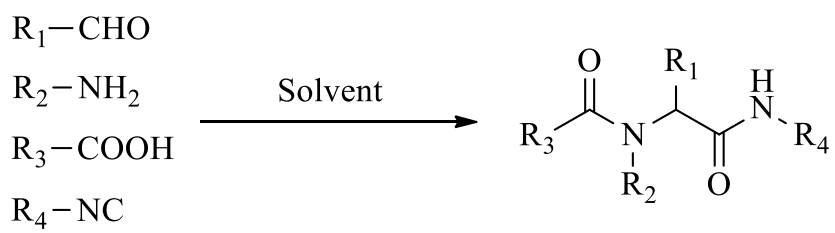

Scheme 1. Ugi 4CR. 
A model reaction using benzaldehyde, aniline, benzoic acid and cyclohexylisocyanide was carried out in the three ionic liquids as solvent as shown in Table 1. In case of (bmim) $\mathrm{PF}_{6}$ the product isolation was difficult as the ionic liquid is hydrophobic and cannot be removed by aqueous extraction and its separation from the product in any organic solvent was not possible. In case of (bmim) $\mathrm{Br}$ the reaction went well at $40^{\circ} \mathrm{C}$ but at room temperature the ionic liquid solidifies and slows down the reaction resulting in incomplete reaction and lower yield.

Table 1. Solvents used for model Ugi reaction at $25{ }^{\circ} \mathrm{C}$

\begin{tabular}{cc}
\hline Solvent & Yields $(\%)$ \\
\hline$\left({\text { bmim }) \mathrm{PF}_{6}}_{(b m i m)} \mathrm{BF}_{4}\right.$ & difficulty in product isolation \\
$(\mathrm{bmim}) \mathrm{Br}\left(\right.$ at $\left.40{ }^{\circ} \mathrm{C}\right)$ & 74 \\
\hline
\end{tabular}

Best results were obtained in (bmim) $\mathrm{BF}_{4}$ and it was found to be the solvent of choice. The hydrophilic character of (bmim) $\mathrm{BF}_{4}$ led to ease of workability and higher yield and purity of the extracted product. On addition of water to the reaction mixture the product separated out as it is water insoluble, while the ionic liquid went into the aqueous phase. The aqueous phase was decanted, washed with water, dried under vacuum to recover and reuse the ionic liquid (bmim) $\mathrm{BF}_{4}$. The residual solid product was dissolved in ethyl acetate, dried and evaporation of solvent followed by column chromatographic purification gave the pure product.

Excellent results were obtained in the formation of compound $\mathbf{1}$ and $\mathbf{2}$ using pmethoxybenzaldehyde which gave a highly pure product in excellent yield. The results show that the ionic liquid media is excellent for carrying out this reaction going via the formation of ionic intermediates resulting in rate acceleration which has been observed in few cases in (bmim) $\mathrm{BF}_{4}$, with most reaction completing in upto $12 \mathrm{~h}$ relative to $24-48 \mathrm{~h}$ reported in literature. Efficient recyclability was observed with no change in the yields and purity of the product formed after three cycles to get product $\mathbf{1}$ (Table 2).

A variety of substrates, such as aliphatic and aromatic aldehydes, amines and acids, were reacted with cylohexylisocyanide in $(\mathrm{bmim}) \mathrm{BF}_{4}$ to give the desired Ugi products as shown in Table 3 in good to excellent yield (55-97\%).<smiles>Nc1ccccc1</smiles><smiles>O=C(O)c1ccccc1</smiles><smiles>COc1ccc(C=O)cc1</smiles><smiles>N#CC1CCCCC1</smiles>
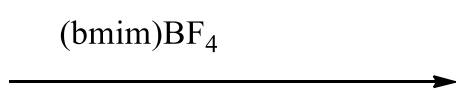
Table 2. Recycling experiments in (bmim) $\mathrm{BF}_{4}$

\begin{tabular}{cc}
\hline Cycle & Yield $(\%)$ \\
\hline $1^{\text {st }}$ & 97 \\
$2^{\text {nd }}$ & 93 \\
$3^{\text {rd }}$ & 94 \\
\hline
\end{tabular}

Table 3. Various Ugi products prepared in (bmim) $\mathrm{BF}_{4}$

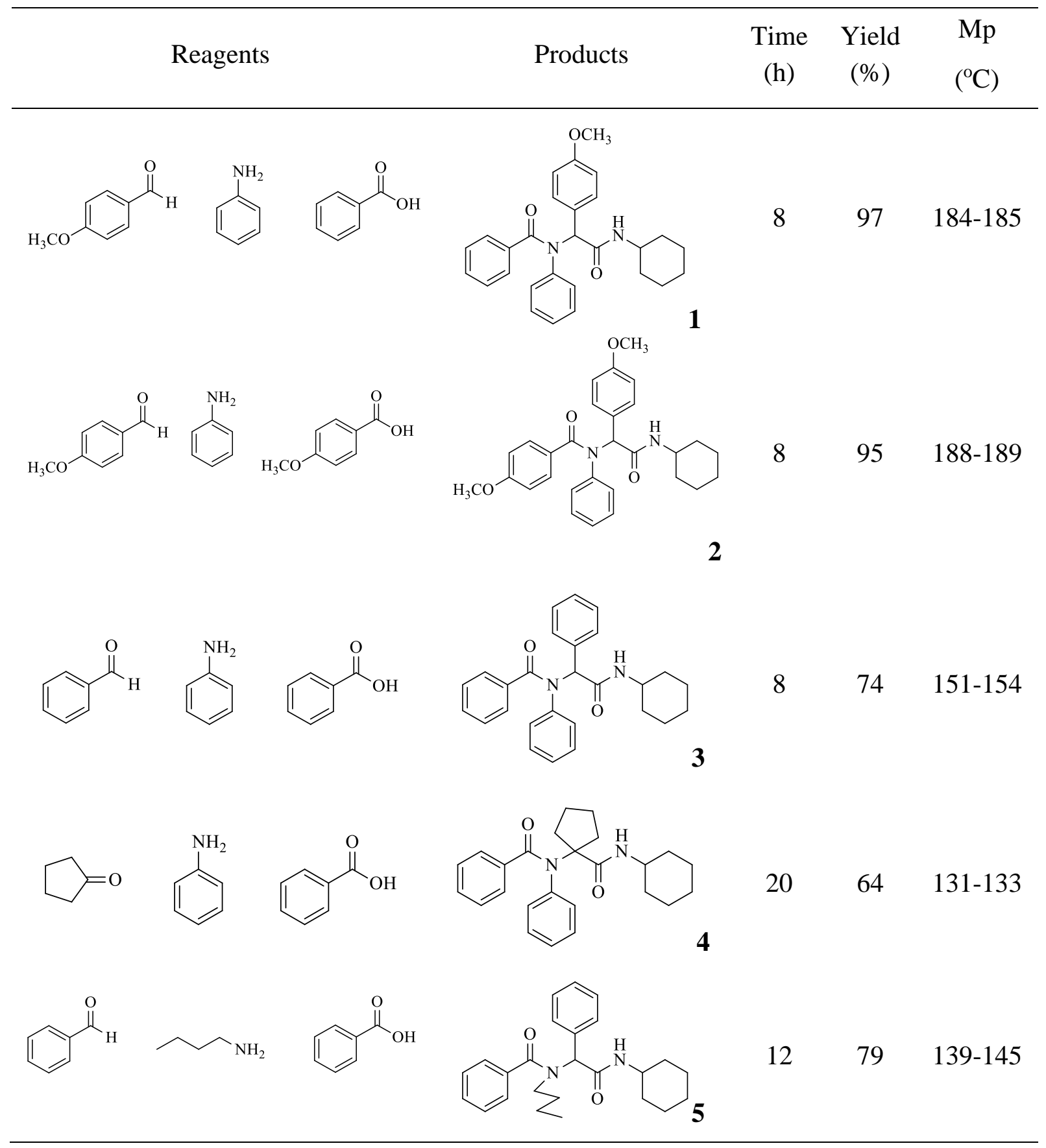


Table 3. Continued

Reagents

For combinatorial synthesis of Ugi adducts, task specific onium salt (TSOS) in (bmim) $\mathrm{BF}_{4}$ has been used as a soluble support for Ugi reaction which works as a binary task specific ionic liquid system (BTSIL) providing a homogenous reaction medium. The onium supported amine, one of the reactants in the Ugi $4 \mathrm{CR}$ has been prepared according to the procedure described in literature. ${ }^{22}$ Firstly, to test the efficacy of the supported system for four component Ugi reaction, the cyclocondensation amongst benzaldehyde, p-methoxy benzoic acid, cyclohexylisocyanide and supported amine was undertaken (Scheme 2). The homogenous nature of the reaction mixture was maintained by dissolving the reactants in room temperature ionic liquid (bmim)BF 4 .

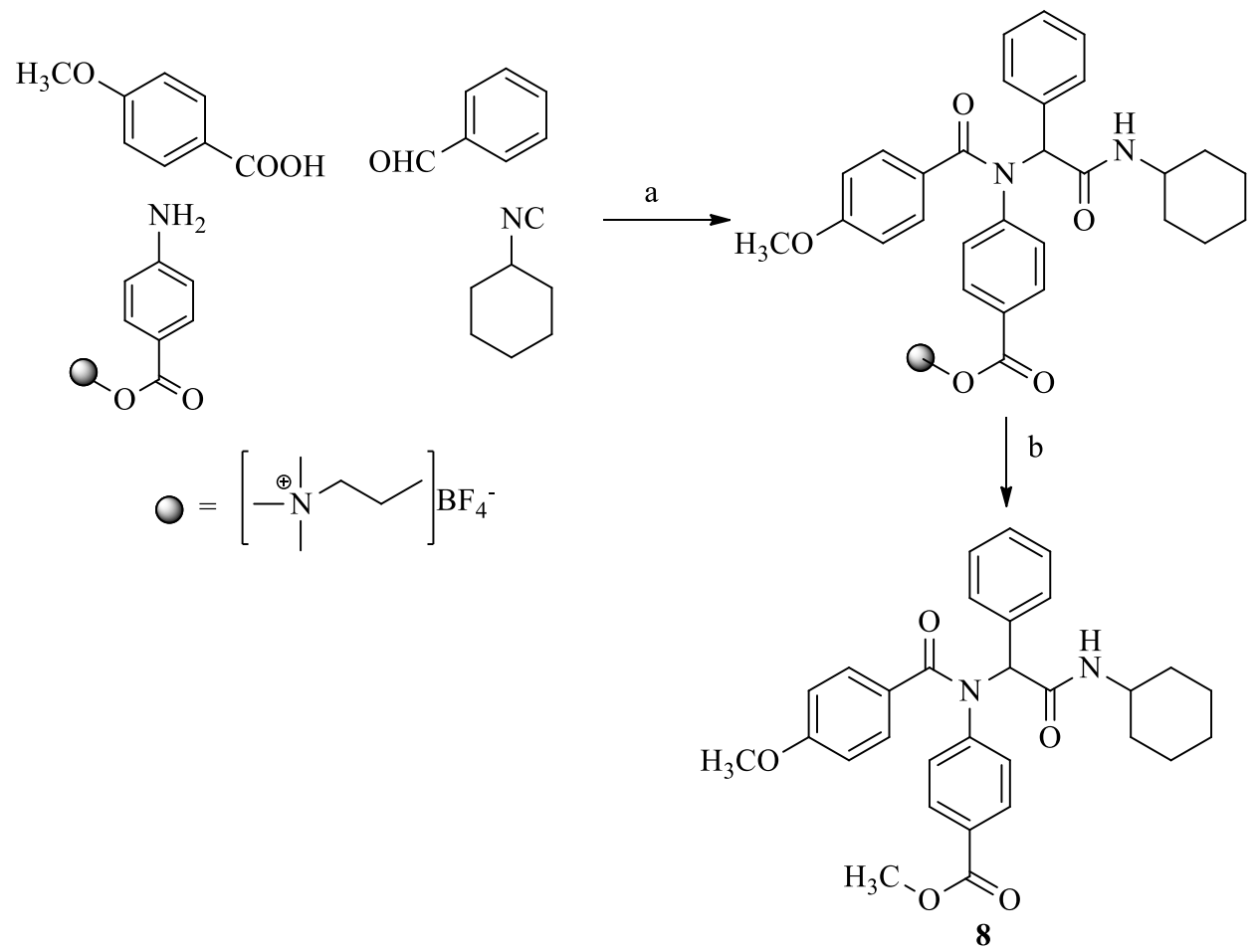

Scheme 2. Reagents and conditions: a: (bmim) BF 4 b: $\mathrm{MeOH}, \mathrm{Et}_{3} \mathrm{~N}$. 
After cleavage of the product from the support, the final compound $\mathbf{8}$ was obtained in $64 \%$ overall yield and was analyzed by its ${ }^{1} \mathrm{H}$ NMR and mass spectral analysis.

After the successful application of ionic liquid bound amine for the synthesis of a single molecule, under homogenous reaction conditions, a small library synthesis of the Ugi compounds was undertaken. For the library synthesis two aldehydes, two acids, one isonitrile and the supported amine were taken as the reacting components (Scheme 3).<smiles>Nc1ccc(C(=O)O)cc1</smiles><smiles>C#CC1CCCCC1</smiles><smiles>C=CC(=O)O</smiles><smiles>O=C(O)c1ccc(N(C(=O)c2ccccc2)C(C(=O)NC2CCCCC2)c2ccccc2)cc1</smiles>

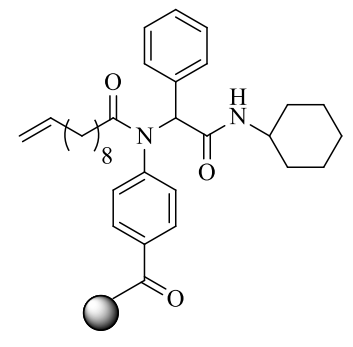

10

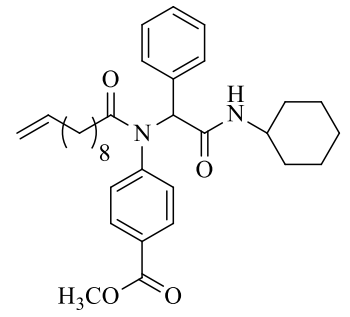

14

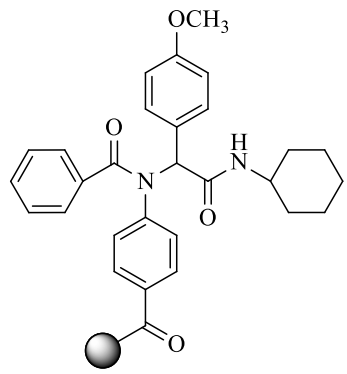

11

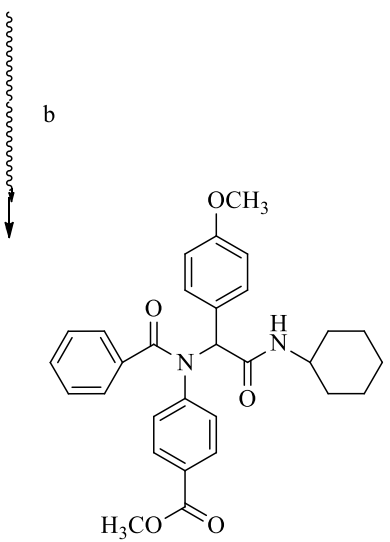

15

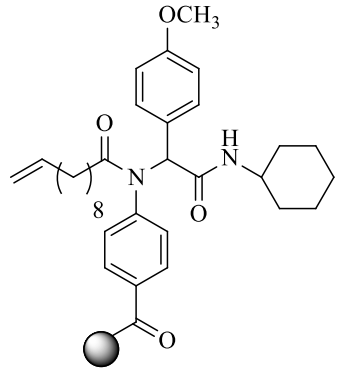

12<smiles>C=CC(=O)N(c1ccc(C(=O)OC)cc1)C(C(=O)NC1CCCCC1)c1ccc(OC)cc1</smiles>

16

Scheme 3. Reagents and conditions: a: (bmim) $\mathrm{BF}_{4}$. b: $\mathrm{MeOH}, \mathrm{Et}_{3} \mathrm{~N}$. 
All the six components were taken in a single pot with (bmim) $\mathrm{BF}_{4}$ as solvent, to obtain a homogenous media. Reaction mixture was stirred at room temperature for $24 \mathrm{~h}$ which provided the onium salt bound $\alpha$-acyl amino amides 9-12. Compounds 9-12 were characterized by the mass spectral analysis wherein the molecular ion peaks for all the four components were present. On cleaving the support, a mixture of small library of four compounds 13-16 were obtained which were identified and confirmed on the basis of the fragmentation pattern on mass spectral analysis of the desired products. The LC-MS of the samples could not be undertaken because of the very close retention time of the four molecules on HPLC analysis.

\section{Conclusions}

On conclusion we have successfully achieved the synthesis of few new $\alpha$-acyl amino in an alternate and recyclable reaction media. The suitable solvent (bmim) $\mathrm{BF}_{4}$ has been identified to give neat products in high yield and good purity. Rate acceleration was also observed in few cases. The ionic liquid supported amine has been used for the synthesis of a small library of $\alpha$ acyl amino amides in a single pot Ugi $4 \mathrm{CR}$ in room temperature ionic liquid (bmim) $\mathrm{BF}_{4}$ as solvent for further application in automated .

\section{Experimental Section}

General. Melting points were determined with a Sunbim melting point apparatus. IR spectra were recorded on a Perkin Elmer model 1430 spectrometer. ${ }^{1} \mathrm{H}$ NMR and ${ }^{13} \mathrm{C}$ NMR spectra were recorded using Joel $300 \mathrm{MHz}$ spectrometer. Chemical shifts are reported in ppm with tetramethylsilane as internal standard. Mass spectra were recorded on Micromass q-Tof Micro (Make: Waters, ESI positive mode).

\section{General reaction procedure}

Aldehyde $(2.5 \mathrm{mmol})$ and amine $(3.0 \mathrm{mmol})$ were dissolved in $(\mathrm{bmim}) \mathrm{BF}_{4}(1.0 \mathrm{~mL})$ in a $50 \mathrm{ml}$ round bottom flask and stirred for one hour. To this reaction mixture was further added acid (3.0 $\mathrm{mmol})$ and cyclohexylisocyanide $(2.5 \mathrm{mmol})$ and continued stirring the mixture till completion of the reaction. Water $(4 \mathrm{~mL})$ was added and the solid product separated out while (bmim) $\mathrm{BF}_{4}$ remained in the aqueous phase. The aqueous layer was decanted and the product was dissolved in ethyl acetate $(10 \mathrm{~mL})$, washed with water $(2 \times 3 \mathrm{~mL})$ and dried over sodium sulphate. The crude product on column chromatographic separation using neural alumina gave pure crystalline product. 


\section{Reaction procedure for combinatorial synthesis}

Aldehyde (2.5 mmol) and [3-(4-aminobenzoyloxy)propyl]trimethylammonium tetrafluoroborate $(3.0 \mathrm{mmol})$ in $\left(\mathrm{Bmim} \mathrm{BF}_{4}(1.0 \mathrm{~mL})\right.$ were taken in a $50 \mathrm{~mL}$ round bottom flask and the reaction mixture was stirred for an hour followed by the addition of acid $(3 \mathrm{mmol})$ and cyclohexylisocyanide $(2.5 \mathrm{mmol})$ and continued stirring the mixture. On completion, the reaction was worked up by addition of water and the residual product was dissolved in ethyl acetate (10 $\mathrm{mL})$, washed with water $(2 \times 3 \mathrm{~mL})$, dried over sodium sulphate. Solvent evaporation gave the crude product to which was added methanol and triethylamine and stirred for $24 \mathrm{~h}$. Methanol and triethylamine were evaporated under vacuum to obtain the mixture as a crude product.

\section{Recycling of (bmim) BF 4}

The aqueous phase, after workup of the reaction mixture, was evaporated under vacuum to remove the water and to get the crude ionic liquid which was washed with ether $(3 \times 5 \mathrm{~mL})$, dried and recycled in the second run. The same process was adopted after each run.

$\boldsymbol{N}$-((Cyclohexylaminocarbonyl)(4-methoxyphenyl)methyl)- $\boldsymbol{N}$-phenylbenzamide (1). IR ( $v_{\max }$, $\left.\mathrm{cm}^{-1}\right): 3420,3020,1676,1636,1250 .{ }^{1} \mathrm{H}$ NMR $\left(300 \mathrm{MHz}, \mathrm{CDCl}_{3}\right): \delta_{\mathrm{H}} 7.26(\mathrm{~d}, 2 \mathrm{H}, J=8.4), 7.16$ $(\mathrm{m}, 5 \mathrm{H}), 6.99(\mathrm{~m}, 5 \mathrm{H}), 6.72(\mathrm{~d}, 2 \mathrm{H}, J=8.4), 6.04(\mathrm{~s}, 1 \mathrm{H}), 5.77\left(\mathrm{~d}, 1 \mathrm{H},-\mathrm{NH}, \mathrm{D}_{2} \mathrm{O}\right.$ exchangeable), $3.84(\mathrm{~m}, 1 \mathrm{H}), 3.74(\mathrm{~s}, 3 \mathrm{H}), 1.94(\mathrm{~m}, 2 \mathrm{H}), 1.65(\mathrm{~m}, 2 \mathrm{H}), 1.38(\mathrm{~m}, 3 \mathrm{H}), 1.12(\mathrm{~m}, 3 \mathrm{H}) .{ }^{13} \mathrm{C} \mathrm{NMR}$ $\left(300 \mathrm{MHz}, \mathrm{CDCl}_{3}\right): \delta_{\mathrm{C}} 170.7,168.5,159.5,141.6,136.3,131.5,130.5,129.3,128.7,127.5$, 127.1, 127.0, 113.8, 65.9, 54.9, 48.6, 33.0, 25.8, 25.0, 24.9. MS (ES+): $m / z=443.2(\mathrm{M}+\mathrm{H})^{+}$. Anal. Calcd. for $\mathrm{C}_{28} \mathrm{H}_{30} \mathrm{~N}_{2} \mathrm{O}_{3}$ : C, 75.99; H, 6.83; N, 6.33\%. Found: C, 75.82; H, 6.91; N, 6.41\%.

$\boldsymbol{N}$-((Cyclohexylaminocarbonyl)(4-methoxyphenyl)methyl)-4-methoxy- $N$-phenylbenzamide (2). IR $\left(v_{\max }, \mathrm{cm}^{-1}\right): 3450,3013,1670,1631,1215 .{ }^{1} \mathrm{H}$ NMR $\left(300 \mathrm{MHz}, \mathrm{CDCl}_{3}\right): \delta_{\mathrm{H}} 7.23(\mathrm{~d}, 2 \mathrm{H}, J=$ 8.4), 7.10 (d, 2H, $J=8.4$ ), $7.02(\mathrm{~m}, 5 \mathrm{H}), 6.72$ (d, 2H, $J=8.7), 6.59$ (d, 2H, $J=8.7), 5.96$ (s, 1H, $\mathrm{CH}), 5.97$ (br s, 1H, -NH, $\mathrm{D}_{2} \mathrm{O}$ exchangeable), $3.79(\mathrm{~m}, 1 \mathrm{H}), 3.75(\mathrm{~s}, 3 \mathrm{H}),, 3.72(\mathrm{~s}, 3 \mathrm{H}), 1.92(\mathrm{~m}$, $2 \mathrm{H}), 1.66(\mathrm{~m}, 2 \mathrm{H}), 1.34(\mathrm{~m}, 3 \mathrm{H}), 1.10(\mathrm{~m}, 3 \mathrm{H}) .{ }^{13} \mathrm{C} \mathrm{NMR}\left(300 \mathrm{MHz}, \mathrm{CDCl}_{3}\right): \delta_{\mathrm{C}} 171.7,166.5$, 159.1, 141.9, 135.3, 131.4, 130.9, 130.2, 129.6, 128.4, 127.5, 127.1, 113.8, 112.8, 64.8, 55.0, 33.0, 25.7, 24.8. MS (ES+): $m / z=473.6(\mathrm{M}+\mathrm{H})^{+}$. Anal. Calcd. for $\mathrm{C}_{29} \mathrm{H}_{32} \mathrm{~N}_{2} \mathrm{O}_{4}: \mathrm{C}, 73.70 ; \mathrm{H}$, $6.82 ; \mathrm{N}, 5.92 \%$. Found: C, 73.78; H, 6.73; N, 6.10\%.

$\boldsymbol{N}$-((Cyclohexylaminocarbonyl)(phenyl)methyl)- $\boldsymbol{N}$-phenylbenzamide $(3)$. IR $\left(v_{\max }, \mathrm{cm}^{-1}\right)$ : 3422, 3018, 1645, 1638, 1215. ${ }^{1} \mathrm{H}$ NMR $\left(300 \mathrm{MHz}, \mathrm{CDCl}_{3}\right): \delta_{\mathrm{H}} 7.01-7.38(\mathrm{~m}, 15 \mathrm{H}), 6.02(\mathrm{~s}, 1 \mathrm{H})$, 5.83(br s, 1H, $\mathrm{D}_{2} \mathrm{O}$ exchangeable), $3.76(\mathrm{~m}, 1 \mathrm{H}), 1.93(\mathrm{~m}, 2 \mathrm{H}), 1.56(\mathrm{~m}, 2 \mathrm{H}), 1.32(\mathrm{~m}, 3 \mathrm{H}), 1.13$ $(\mathrm{m}, 3 \mathrm{H}) .{ }^{13} \mathrm{C}$ NMR $\left(300 \mathrm{MHz}, \mathrm{CDCl}_{3}\right): \delta_{\mathrm{C}} 171.6,169.7,137.2,136.9,134.4,131.0,127.8,126.4$, 126.1, 124.1, 120.4, 66.1, 50.4, 33.0, 25.9, 23.6. MS (ES+): $m / z=413.3(\mathrm{M}+\mathrm{H})^{+}$. Anal. Calcd. for $\mathrm{C}_{27} \mathrm{H}_{28} \mathrm{~N}_{2} \mathrm{O}_{2}$ : C, 78.61; H, 6.84; N, 5.05\%. Found: C, 78.77; H, 6.71; N, 5.12\%.

$N$-(-1-(Cyclohexylaminocarbonyl)cyclopentyl)- $N$-phenylbenzamide (4). IR $\left(v_{\max }, \mathrm{cm}^{-1}\right): 3448$, 3030, 1654, 1560. ${ }^{1} \mathrm{H}$ NMR (300 MHz, $\left.\mathrm{CDCl}_{3}\right): \delta_{\mathrm{H}} 7.17-7.02(\mathrm{~m}, 10 \mathrm{H}), 3.84(\mathrm{~m}, 1 \mathrm{H}), 2.47(\mathrm{~m}$, $4 \mathrm{H}), 1.97-1.19(\mathrm{~m}, 14 \mathrm{H}) .{ }^{13} \mathrm{C} \mathrm{NMR}\left(300 \mathrm{MHz}, \mathrm{CDCl}_{3}\right): \delta_{\mathrm{C}} 175.2,164.3,135.5,134.2,129.4$, $128.9,128.7,127.6,127.2,124.4,121.3,121.1,65.0,48.4,33.3,30.5,30.1,22.2,15.3,13.2 . \mathrm{MS}$ $(\mathrm{ES}+): \mathrm{m} / z=403.4(\mathrm{M}+\mathrm{H})^{+}$. 
$\boldsymbol{N}$-((Cyclohexylaminocarbonyl)(phenyl)methyl)- $\boldsymbol{N}$-butylbenzamide (5). IR (vmax, $\left.\mathrm{cm}^{-1}\right): 3434$, 3021, 1642, 1635. ${ }^{1} \mathrm{H}$ NMR $\left(300 \mathrm{MHz}, \mathrm{CDCl}_{3}\right), \delta_{\mathrm{H}} 7.60-7.25(\mathrm{~m}, 10 \mathrm{H}), 6.23$ ( s, 1H), 6.00( br s, $1 \mathrm{H}, \mathrm{D}_{2} \mathrm{O}$ exchangeable $): 3.80(\mathrm{~m}, 1 \mathrm{H}), 3.28(\mathrm{t}, 2 \mathrm{H}), 1.92-0.92(\mathrm{~m}, 17 \mathrm{H}) .{ }^{13} \mathrm{C} \mathrm{NMR}(300 \mathrm{MHz}$, $\left.\mathrm{CDCl}_{3}\right): \delta_{\mathrm{C}} 166.9,164.5,136.9,135.9,133.8,129.2,128.7,128.5,128.4,128.3,127.4,136.7$, 63.2, 48.4, 48.1, 33.0, 32.9, 29.8, 25.6, 24.8, 19.9, 13.5. MS (ES+): $m / z=392.3(\mathrm{M}+\mathrm{H})^{+}$. Anal. Calcd. for $\mathrm{C}_{25} \mathrm{H}_{32} \mathrm{~N}_{2} \mathrm{O}_{2}$ : C, 76.49; H, 8.21; N, 7.13\%. Found: C, 76.61; H, 8.06; N, 6.98\%.

$\boldsymbol{N}$-(-1-(Cyclohexylaminocarbonyl)-3-methylbutyl)- $\boldsymbol{N}$-butylundec-10-enamide (6). IR ( $v_{\max }$, $\left.\mathrm{cm}^{-1}\right): 3681,3018,1675,1629 .{ }^{1} \mathrm{H}$ NMR $\left(300 \mathrm{MHz}, \mathrm{CDCl}_{3}\right): \delta_{\mathrm{H}} 7.24(\mathrm{~m}, 5 \mathrm{H}), 5.98(\mathrm{~s}, 1 \mathrm{H}), 5.69$ $(\mathrm{m}, 1 \mathrm{H}), 4.90(\mathrm{~m}, 2 \mathrm{H}), 3.70(\mathrm{~m}, 1 \mathrm{H}), 3.19(\mathrm{t}, 2 \mathrm{H}), 2.28(\mathrm{t}, 2 \mathrm{H}), 1.99-0.67(\mathrm{~m}, 29 \mathrm{H}) .{ }^{13} \mathrm{C} \mathrm{NMR}$ (300 MHz, $\mathrm{CDCl}_{3}$ ): $\delta_{\mathrm{C}} 173.6,168.8,138.8,136.1,129.3,128.6,128.1,114.5,62.2,48.3,46.8$, $33.9,33.5,32.9,32.8,32.0,29.6,29.5,29.2,29.0,25.7,25.5,24.9,20.2,13.7 . \mathrm{MS}(\mathrm{ES}+): \mathrm{m} / z=$ $421.8(\mathrm{M}+\mathrm{H})^{+}$.

2-( $N$-butylbutyramido)- $\boldsymbol{N}$-cyclohexyl-4-methylpentanamide (7). IR ( $\left.v_{\max }, \mathrm{cm}^{-1}\right): 3580,3012$, 1670, 1635. ${ }^{1} \mathrm{H}$ NMR (300 MHz, $\left.\mathrm{CDCl}_{3}\right): \delta_{\mathrm{H}} 4.26$ (br s, 1H), $4.12(\mathrm{~s}, 1 \mathrm{H}), 3.50(\mathrm{~m}, 2 \mathrm{H}), 2.96(\mathrm{t}$, $2 \mathrm{H}), 1.90(\mathrm{~m}, 1 \mathrm{H}), 1.08-1.74(\mathrm{~m}, 23 \mathrm{H}), 0.91(\mathrm{~d}, 6 \mathrm{H}) .{ }^{13} \mathrm{C} \mathrm{NMR}\left(300 \mathrm{MHz}, \mathrm{CDCl}_{3}\right): \delta_{\mathrm{C}} 173.2$, 169.4, 58.6, 46.1, 44.9, 35.1, 33.7, 32.8, 32,6, 32.0, 30.5, 29.6, 29.2 , 25.7, 25.1, 24.2, 19.4, 18.4, 13.4. MS (ES+): $m / z=339.6(\mathrm{M}+\mathrm{H})^{+}$. Anal. Calcd. for $\mathrm{C}_{20} \mathrm{H}_{38} \mathrm{~N}_{2} \mathrm{O}_{2}: \mathrm{C}, 70.95 ; \mathrm{H}, 11.31 ; \mathrm{N}, 8.27$. Found: C, 71.07; H, 11.21; N, 8.13\%.

Compound (8). ${ }^{1} \mathrm{H}$ NMR $\left(300 \mathrm{MHz}, \mathrm{CDCl}_{3}\right)$ : $\delta_{\mathrm{H}} 7.93(\mathrm{~d}, 2 \mathrm{H}), 7.87(\mathrm{~d}, 2 \mathrm{H}), 7.81(\mathrm{~d}, 2 \mathrm{H}), 7.14$ $(\mathrm{m}, 5 \mathrm{H}), 6.78(\mathrm{~d}, 2 \mathrm{H}), 6.01(\mathrm{~s}, 1 \mathrm{H}), 5.34\left(\mathrm{~d}, 1 \mathrm{H}, \mathrm{D}_{2} \mathrm{O}\right.$ exchangeable), $3.79(\mathrm{~m}, 1 \mathrm{H}), 3.74(\mathrm{~s}, 3 \mathrm{H})$, $1.94(\mathrm{~m}, 2 \mathrm{H}), 1.65(\mathrm{~m}, 2 \mathrm{H}), 1.38(\mathrm{~m}, 3 \mathrm{H}), 1.12(\mathrm{~m}, 3 \mathrm{H})$; MS (ES+): $m / z=501.3(\mathrm{M}+\mathrm{H})^{+}$.

Compounds (9-12). MS (ES+): $m / z=648.5(\mathrm{M})^{+}\left(\right.$Compound 12), $618.5(\mathrm{M})^{+}($Compound 10), $586.3(\mathrm{M})^{+}$(Compound 11), $556.3(\mathrm{M})^{+}$(Compound 9).

Compound (13). MS (ES+): $m / z=411.4,372.2,351.1,313.8,77.0$.

Compound (14). MS (ES+): $m / z=473.0,434.2,374.2,351.1,77.0$.

Compound (15). MS (ES+): $m / z=441.3,402.4,374.4,343.6,297.3$, 77.0.

Compound (16). MS (ES+): $m / z=503.4,464.4,405.2,297.3,77.0$.

\section{Acknowledgements}

The authors are thankful to CSIR and CEFIPRA, New Delhi for providing financial assistance.

\section{References}

1. Wender, P. A.; Handy, S. T.; Wright, D. L. Chem. Ind. 1997, 765.

2. (a) Armstrong, R.; Combs, A.; Tempest, P.; Brown, D.; Keating, T. Acc. Chem. Res. 1996, 29, 123. (b) Bienayme, H.; Hulme, C.; Oddon, G.; Schmidt, P. Chem- Eur. J. 2000, 6, 3321. 
3. (a) Pitlik, J.; Townsend, C. A. Bioorg. Med. Chem. Lett. 1997, 7, 3129. (b) Hanush-Kompa, C. Tetrahedron Lett. 1998, 39, 2725.

4. Ugi, I. Pure Appl. Chem. 2001, 73, 187.

5. (a) Keating, T. A.; Armstrong, R. W. J. Org. Chem. 1996, 61, 8935. (b) Hulme, C.; Peng, J.; Tang, S. Y.; Burns, C. J.; Morize, I.; Labaudiniere, R. J. Org. Chem. 1998, 63, 8021. (c) Hulme, C.; Cherrie, M. P. Tetrahedron Lett. 1999, 40, 5295.

6. Kim, Y. B.; Choi, E. H.; Keum, G.; Kang, S. B.; Lee, D. H.; Koh, H. Y.; Kim, Y. Org. Lett. 2001, 3, 4149.

7. Nixey, T.; Kelly, M.; Hulme, K. Tetrahedron Lett. 2000, 41, 8729.

8. Hulme, C.; Moeeissette, M. M.; Volz, F. A.; Burns, C. J. Tetrahedron Lett. 1998, 39, 1113.

9. Park, S. J.; Keum, G.; Kang, S. B.; Koh, H. Y.; Lee, D. H.; Kim, Y. Tetrahedron Lett. 1998, 39, 7109.

10. Musonda, C. C.; Taylor, D.; Lehman, J.; Gut, J.; Rosenthal, P. J.; Chibal, K. Bioorg. Med. Chem. Lett. 2004, 3901.

11. Li, Z.; Yeo, S. L.; Pallen, C. J.; Ganeshan, A. Bioorg. Med. Chem. Lett. 1998, 8, 2443.

12. Sheehan, S. M.; Masters, J. J.; Wiley, M. R.; Young, S. C.; Liebeschuetz, J. W.; Jones, S. D.; Murray, C. W.; Frenciskovich, J. B.; Engel, D. B.; Weber, W. W.; Marimuthu, J.; Kyle, J. A.; Smallwood, J. K.; Farmen, M. W.; Smith, G. F. Bioorg. Med. Chem. Lett. 2003, 13, 2255.

13. Ugi, I. Angew. Chem. Int. Ed. 1962, 1, 8.

14. Domling, A.; Ugi, I. Angew. Chem. Int. Ed. 2000, 39, 3168.

15. Pirrung, M. C.; Sarma, K. D. J. Am. Chem. Soc. 2004, 126, 444.

16. (a) Welton, T. Chem. Rev. 1999, 99, 2071. (b) Earl, M. J.; Seddon, K. R. Ionic liquids. Pure Appl. Chem. 2000, 72, 1391.

17. Wasserscheid, P.; Welton, T. Ionic Liquids in Synthesis; Wiley-VCH: Weinheim, 2003.

18. Mehnert, C. P.; Cook, R. A.; Dispenziere, N. C.; Afeworki M. J. Am. Chem. Soc. 2002, 124, 12932.

19. Hulme, C. Multicomponent reactions; Zhu, J., Bienayme, H., Eds.; Wiley: Weinheim, 2005; p 328.

20. (a) Bao, W.; Wang, Z.; Li, Y. J. Org. Chem. 2003, 68, 591. (b) Larsen, A. S.; Holdbrey, J. D.; Tham, F. S.; Reed, C. A. J. Am. Chem. Soc. 2000, 122, 7264. (c) Gu, Y.; Shi, F.; Deng, Y. J. Org. Chem. 2004, 69, 391.

21. (a) Singh, V.; Kaur, S.; Sapehiyia, V.; Singh, J.; Kad, G. L. Catal. Commun. 2005, 6, 57. (b) Singh, J.; Gupta, N.; Kad, G. L.; Kaur, J. Synthetic Communication 2006, 36, 2893.

22. Hassine, F.; Gmouth, S.; Pacheault, M.; Vaultier, M. Monatshefte fur Chemie 2007, 138, 1167. 